\title{
Culture and Diversity in John Stuart Mill's Civic Nation
}

\author{
JASON TYMDAL \\ Tulane University
}

\begin{abstract}
In this article, I develop a conception of multiculturalism that is compatible with Mill's liberal framework. I argue, drawing from Mill's conception of the nation-state, that he would expect cultural minorities to assimilate fully into the political sphere of the dominant culture, but to assimilate only minimally, if at all, into the cultural sphere. I also argue that while Mill cannot permit cultural accommodations in the form of self-government rights, he would allow for certain accommodation rights (construed as individual rights) which assist cultural minorities in preserving their cultural particularity. While this is indeed a modest multiculturalism, it helps to demonstrate that Mill was not as hostile towards custom or minority groups as certain passages may appear to suggest.
\end{abstract}

\section{INTRODUCTION}

Jeremy Waldron has suggested that there is good reason to think that John Stuart Mill would have been hospitable to some form of multiculturalism. ${ }^{1}$ In its most general form, multiculturalism is the idea that a standard basket of individual rights is insufficient to protect minority cultures from disappearing under the influence of the majority culture. Thus, special group rights, known as cultural accommodations, are necessary if we desire to preserve cultural differences. Waldron, however, is hesitant to lay out a sharply drawn account of Millian multiculturalism given that Mill's discussions on practical matters are sometimes 'nuanced and hesitant'. ${ }^{2}$ Nevertheless, he develops two general claims which are helpful in laying the groundwork for a Millian multiculturalism. The first is that the justification for a Millian multiculturalism must be traced to the value placed on cultural diversity 'as a means to [social] progress'. ${ }^{3}$ The second claim is that this multiculturalism could apply only to groups that do not inflict wrongful harm on individual group members by infringing upon their basic liberties. $^{4}$

1 Jeremy Waldron, 'Mill and Multiculturalism', Mill's On Liberty: A Critical Guide, ed. C. L. Ten (New York, 2008), pp. 165-84.

2 Waldron, 'Mill', p. 183.

3 Waldron, 'Mill', p. 183

${ }^{4}$ Waldron, 'Mill', pp. 179-81. While Waldron speaks simply of harm, I will use the term 'wrongful harm' to refer to a perceptible loss or damage that was not voluntarily consented to. While harm may include things such as physical damage, financial loss or 
My purpose in this article is to expand on Waldron's claims and to develop more fully a conception of multiculturalism compatible with Mill's liberal framework. While I agree with Waldron that Mill's discussions on practical matters are not always understandable through the lens of either his moral or political philosophy, I hope that an articulation of his multiculturalism will better position us to determine whether or not certain practical conclusions - where cultural minorities are concerned - are consistent with his theoretical framework.

I will begin by discussing Mill's conception of the nation-state. This is necessary to lay the groundwork for a Millian multiculturalism. I will argue that Mill conceives of the nation-state as a civic nation and that, because of this, he would expect cultural minorities to assimilate fully into the political sphere of the dominant culture, but to assimilate only minimally, if at all, into the cultural sphere. I will also argue that while Mill would reject any claims by cultural minorities to self-government, it is consistent with his principle of liberty and his conception of the nation-state to permit cultural accommodations that assist cultural minorities in preserving their cultural particularity. However, such accommodations can be justified only if they (1) promote diversity as a means to social progress; (2) do not impede the political assimilation of cultural minorities; and (3) do not enable groups to restrict the basic civil and political liberties of their individual members (or nonmembers). Given these constraints, a significant portion of this article is devoted to showing how each of these three conditions can be met within a Millian framework.

\section{MILL'S CIVIC NATION}

In Considerations on Representative Government (CRG), Mill shares with us his conception of nationality: '[a] portion of mankind may be said to constitute a Nationality, if they are united among themselves by common sympathies, which do not exist between them and any others'. ${ }^{5}$ While it is clear that the 'common sympathies' are the centrepiece of Mill's conception of nationality, Mill never tells us exactly what these sympathies are. This omission has created an interpretative challenge for readers of Mill. How one interprets the opening passage of chapter sixteen of $C R G$ will influence how one proceeds to interpret not only Mill's views on nation-building, but also his views on cultural minorities. For this reason, I begin this section with my own interpretation of Mill's notion of common sympathies.

damage to reputation, I am primarily concerned with the infringement of basic rights and liberties.

5 John Stuart Mill, Considerations on Representative Government, Collected Works of John Stuart Mill, vol. 19, ed. J. M. Robson (Toronto, 1977), p. 546. 
On my construal, an analysis of the common sympathies should begin with the realization that Mill has located them within a causal chain. While he does not explicitly tell us what the common sympathies are, he does tell us what causes them and what, in turn, they cause. First, as Mill conceives it, the existence of common sympathies amongst a community of people has the following threefold effect: it 'make[s] them co-operate with each other more willingly than with other people, desire to be under the same government, and desire that it should be government by themselves or a portion of themselves, exclusively'. ${ }^{6}$ These three impulses constitute what Mill calls a 'feeling of nationality'.

This feeling of nationality may have been generated by various causes. Sometimes it is the effect of identity of race and descent. Community of language, and community of religion, greatly contribute to it. Geographical limits are one of its causes. But the strongest [cause] of all is identity of political antecedents; the possession of a national history, and consequent community of recollections; collective pride and humiliation, pleasure and regret, connected with the same incidents in the past. None of these circumstances however are either indispensable, or necessarily sufficient by themselves. ${ }^{7}$

Mill has spoken too loosely here. He has already told us that the common sympathies are the cause of the feeling of nationality. Yet, in this passage, Mill appears to be claiming that it is the various forms of 'identity' that cause the feeling of nationality. This may encourage readers to conclude that the common sympathies are merely these various forms of identity. But that cannot be right. For if it is the common sympathies that unite citizens of a nation, and these sympathies are nothing more than forms of identity, then that suggests that Mill might want national boundaries to be drawn according to race, ethnicity, political antecedents, and so on. But such a view would conflict with Mill's claim that none of these forms of identity 'are either indispensable or necessarily sufficient by themselves'. Further, Mill nowhere advocates the drawing of national boundaries in such a way.

In the passage in question, then, Mill can only be specifying the circumstances which he believes will most likely give rise to the common sympathies. Nevertheless, while I have accused Mill of speaking too loosely, what tension there is in the passage can be explained. Because the common sympathies do give rise to the three impulses that constitute the feeling of nationality, it is not wholly mistaken to claim that the various forms of identity are causes of the feeling of nationality. Still, what Mill should have said - and what I think he had in mind - is that the various forms of identity are direct

6 Mill, Considerations, p. 546.

7 Mill, Considerations, p. 546. 
causes of the common sympathies and only indirect causes of a feeling of nationality. Let us now review the full causal chain.

The various forms of identity (whether of race, ethnicity, political antecedents, etc.) cause the common sympathies. Then, the existence of common sympathies amongst a community of people encourages three impulses: (1) the desire to cooperate; (2) the desire to come together under a single government; and (3) the desire for that government to be a government by the people, or by a portion of the people. Finally, these three impulses constitute a 'feeling of nationality'. As such, we have a tripartite distinction between the forms of identity, the common sympathies and a feeling of nationality. While we have a clear understanding of what Mill means by the forms of identity and a feeling of nationality, it is not yet clear what exactly the common sympathies are.

Thus far, two features of Mill's notion of common sympathies are discernible. First, we know what Mill thinks will often give rise to common sympathies (i.e. the various forms of identity). Second, we know what political effect he thinks the existence of common sympathies will have on a community. The second feature is most informative. That the common sympathies are said to produce the three impulses that they do suggests that they are political in character. Mill's notion of common sympathies, I propose, refers broadly to the shared hopes, concerns and expectations of a group of individuals with respect to political matters. Indeed, people who share similar political concerns and expectations will be more inclined to cooperate with one another and to want to come together under a government that is both for the people and by the people (or a portion thereof). Moreover, there is no denying that the various forms of identity, especially that of political antecedents, play a role in shaping one's political concerns and expectations.

The common sympathies must be characterized as broad on the grounds that it would be improper to include particular beliefs, individual life choices, or either family or cultural customs in this category. A nation is united by common sympathies not because each citizen has the same goals in life, but because there is an overarching political unity present amongst the people. To emphasize the political nature of the common sympathies, I will refer to them as political sympathies.

Mill recognized that obstacles to communication posed a serious challenge to the sharing of political sympathies. For this reason, he was especially concerned with identifying the conditions upon which 'united public opinion' could be achieved. ${ }^{8}$ For any nation to be united in public opinion, Mill thought, its people must have the ability and opportunity to compare their own opinions with those of others. Where individuals

8 Mill, Considerations, p. 547. 
are encouraged to publicize their opinions to one another, there exists a greater chance of creating a nation of politically coalescing and cooperative individuals that will remain candid about their opinions and the sources of their influence.

While Mill notes that this sort of free and transparent public domain is an institution that must be established and protected by the state, he thinks there are some inherent limitations that must guide its establishment. Mill argues that a state of non-coalescing individuals (i.e. a state comprised of multiple nations) could never be sure of the sympathies of others since they, presumably, could not establish a transparent public domain in which all nations could effectively and cooperatively participate. ${ }^{9}$ Instead, these individuals must rely on the state to be fair in its treatment of all nations. But citizens could never be sure that a multinational state is being fair. Without the proper transparency, Mill thinks that public communication will suffer and each nation will grow suspicious of the motivations of others. Consequently, nation-specific interests will flourish and this, in turn, will encourage national isolation. Finally, multinational states would employ armies representing an erratic and dispersed patriotism. Yet, armies should be defenders of the people, not the government; and as soon as military personnel feel no duty - no connection - to the people they should serve, they become a mere handmaiden of despotism. As Mill declares, such Armies are the 'executioners of liberty'. ${ }^{10}$

Mill's worry here is that a multinational state would be subject to manipulation by the government since multiple nations could only be superficially tied together under one state. Thus, they would be prevented from intermingling with one another and would be situated in such a way that each nation is pitted against the other(s). Where this is accomplished, the government could rule despotically without fear of reprisal, especially in cases where aggrieved nations do not 'feel that they can rely on the others for fidelity in a joint resistance.' ${ }^{11}$ The motivation to avoid just such a scenario is what underpins Mill's advocacy of the nation-state. The threat of this resistance - which Mill finds to be a feature of nation-states - is an essential security against despotism. ${ }^{12}$ As he says, '[f]ree institutions are next to impossible in a

9 Mill, Considerations, p. 547. This is Mill's key assumption: the idea that a multinational state could never (or at least almost never) promote the coalescing of individuals needed to establish a free and transparent public domain through which opinions can be shared. For the purpose of this article, however, I wish to set aside this issue in order to determine how such assumptions impact a multiculturalism that can be drawn out of Mill's political theory.

10 Mill, Considerations, p. 548.

11 Mill, Considerations, p. 547.

12 Mill, Considerations, p. 547. 
country made up of different nationalities'. ${ }^{13}$ Thus, on Mill's account, if free institutions are the goal, 'the boundaries of government should coincide in the main with those of nationalities' ${ }^{14}$ Having multiple nations under a single state would be a nearly incorrigible obstacle to the sharing of political sympathies.

To summarize, a sharing of political sympathies - i.e. political hopes, concerns and expectations - is needed to motivate effective cooperation and political participation. This level of cooperation and participation is necessary if 'united public opinion' is to be a possibility. But achieving united public opinion requires more than a citizenship prepared to cooperate and participate, it also requires a transparent public domain. As Mill understands it, such a domain, if it is to be stable, calls for the framework provided by nation-states.

It is worth noting that Mill regards the idea that government boundaries should coincide with single nationalities as constituting his 'general principle' concerning the relationship between nationality and government. ${ }^{15}$ In other words, it is his preferred position in ideal circumstances. Yet, special circumstances may warrant deviating from the general principle. Such is the topic of chapter seventeen of $C R G$. There, Mill considers what circumstances would justify the forming of a federation. I do not want to say much about that particular discussion here. I will only point out that the circumstances must be extenuating to warrant the formation of anything other than a nation-state.

It is important to continue filling out Mill's picture of the nation-state. Doing so will provide us with key insights regarding the extent to which Mill would expect citizens to engage with one another. On the classical account of nationalism, the loyalties of the group are rooted in a shared ethnicity, which usually identifies with some particular language and set of customs. ${ }^{16}$ However, as can be seen from the conception of shared political sympathies presented above, the importance of nationhood, for Mill, traces not to ethnic loyalties, but to civic loyalties. While the sharing of a common language, religion or ethnicity is a powerful reason to unite, these are neither necessary nor sufficient motivators. ${ }^{17}$ What is necessary, however, is that all members of a polity be motivated by their shared concerns and expectations to participate effectively and cooperatively in the public domain. As such, all members of society

\footnotetext{
13 Mill, Considerations, p. 547.

14 Mill, Considerations, p. 548.

15 Mill, Considerations, p. 548.

16 Nenad Miscevic, 'Nationalism', Stanford Encyclopedia of Philosophy, $<$ http://plato.stanford.edu/entries/nationalism/> (2010).

17 Mill notes the strong sense of nationality among the subjects of the cantons of Switzerland which do not share a common race, language or religion; see Mill, Considerations, p. 546.
} 
have a civic role to play. So, in stressing the civic foundation of Mill's nationalism, we can regard the citizens of such a state as comprising a civic nation.

Up to this point, I have made two claims. The first is that Mill is an advocate of the nation-state. The second is that Mill conceives of the nation-state as a civic nation. In the next section, I will turn to defining the degree of assimilation expected of cultural minorities entering into a Millian civic nation.

\section{MILL'S ASSIMILATION EXPECTATIONS}

The main claim of this section is that Mill would expect cultural minorities to assimilate into the dominant culture, but that this assimilation would be limited almost entirely to political assimilation, not cultural assimilation. It is crucial then to distinguish between these two types of assimilation. Individuals culturally assimilate into a society when they not only learn the language of that society, but also adopt its practices, traditions, values, etc. Alternatively, it is by the process of political assimilation that individuals become capable of fully participating in political life. This entails the ability to engage in the political process: to vote, to express one's political concerns and to participate in ongoing political dialogue. It is by participating in political life that individuals become capable of shaping the political policies of a society, including its social, economic and educational standards.

Mill, I have argued, desired to create a nation of coalescing individuals bonded by shared political sympathies which motivate their cooperation and participation in the public domain. We should be careful, however, to distinguish the political community from its social $^{18}$ and cultural groups. The development of effective cooperation and political participation does not require cultural minorities to part with the customs or traditions that provide a context from which to evaluate, set and revise life pursuits. As noted above, the political sympathies which provide the basis for the effective cooperation and participation are broad in character. Members in a society can debate about social and political matters without having to agree on the particulars of what constitutes a good life. C. L. Ten captures this concern nicely with regard to liberalism in general.

Liberalism acknowledges the central importance of a political community with a shared political morality. But a liberal society is not a comprehensive social

18 The term 'social' is used here in a narrow sense to denote groups that may not be regarded as cultural, but whose members share commonalities with respect to practices or life pursuits. Political life is indeed social, but in a broader sense of the term. 
community with very specific common ends and goals, and shared values pervading the whole of social life. It has many social and cultural communities which unite into one political community. ${ }^{19}$

I do not mean to imply that the political and cultural aspects of life are distinct from one another in the strongest sense of the term. It would be a mistake to suggest that the experiences derived from social and cultural groups do not inform and shape opinions in the political domain. The point to be made is that political life does not demand any particular social and cultural background. All it presupposes, on Mill's account, is the existence of political sympathies, which are themselves compatible with a variety of social and cultural backgrounds.

A Millian society could be composed of numerous cultural groups each offering its own set of values and goals - that constitute the single political community. In other words, cultural heterogeneity is compatible with political homogeneity. So, when talking about the integration of cultural minorities, Mill is concerned only with political assimilation. He wants all citizens to have the capacity and venue to exert their influence on the social and political fabric of the state. Mill's worries about the pitfalls of cultural homogeneity are expressed in his criticisms of China. China has become stationary in terms of progress, he says, because 'they have succeeded beyond all hope in what English philanthropists are so industriously working at - in making a people all alike'. ${ }^{20}$

It should be observed, however, that the possibility of political assimilation might, in certain cases, require at least some minimal degree of cultural assimilation, but the cultural assimilation is not so great as to warrant disregarding the distinction. It is evident that Mill would expect some level of cultural assimilation (under certain circumstances) when he remarks that '[a]mong a people without fellowfeeling, especially if they read and speak different languages, the united public opinion, necessary to the working of representative government, cannot exist'. ${ }^{21}$ And in his discussion of the French Revolution, Mill says:

When portions of mankind, living under the same government, cherish ... barbarous feelings - when they feel towards each other as enemies, or as strangers, indifferent to each other - they are scarcely capable of merging into one and the same free people. They have not the fellow-feeling which would enable them to unite in maintaining their liberties, or in forming a paramount public opinion. The separation of feeling which mere difference of

19 C. L. Ten, Multiculturalism and the Value of Diversity (Singapore, 2004), p. 3.

20 John Stuart Mill, On Liberty, in Collected Works of John Stuart Mill, vol. 18, ed. J. M. Robson (Toronto, 1977), p. 273.

21 Mill, Considerations, p. 547. 
language creates, is already a serious hindrance to the establishment of a common freedom. ${ }^{22}$

It is probable, then, that Mill would adopt a policy of commonlanguage acquisition for incorporated minorities. ${ }^{23}$ This should not, however, prompt us to reconsider whether Mill conceives of the nationstate as an ethnic nation, for Mill would not limit integration on the basis of ethnicity, race, religion, etc. (as ethnic nations often do). $\mathrm{He}$ would, however, probably argue that common-language acquisition would empower minorities to participate in the political domain and arm them with political influence as a means to protecting their own rights. In other words, a minimal amount of cultural assimilation is needed to create the background conditions for political assimilation.

That Mill could expect, at most, this minimal level of cultural assimilation does not yet constitute a conception of multiculturalism. Indeed, his respect for cultural minorities could well be limited to a stance of mere toleration on a par with the notion of religious toleration. On such an account, particular values are not discriminated against, but neither are they protected by state policies. So, while Mill provides space for cultural minorities to express cultural values, it is not obvious that he would be willing to utilize the political arm actively to protect those values through cultural accommodations. What is needed, then, is a specific argument for multiculturalism that is compatible with Mill's conception of the civic nation.

\section{THE ARGUMENT FROM DIVERSITY}

When talking about multiculturalism, it is helpful to distinguish between two common approaches. One justifies cultural accommodations on the basis of an appeal to equality concerns (of some sort), while the other justifies them by an appeal to the importance of diversity. I want to suggest, along with Waldron, that if a theory of Millian multiculturalism can be defended, it is one that traces its justification to the importance of diversity.

While Mill is sometimes interpreted as hostile towards custom, such a characterization is unfair. Mill does not direct his criticism at custom itself, but rather at individuals who rely solely and uncritically on custom when making life choices.

\footnotetext{
22 John Stuart Mill, Vindication of the French Revolution of February 1848, Collected Works of John Stuart Mill, vol. 20, ed. J. M. Robson (Toronto, 1985), p. 347, emphasis added.

${ }^{23}$ Cultural minorities could certainly choose to become bilingual rather than entirely dispense with the language of their culture.
} 
No one's idea of excellence in conduct is that people should do absolutely nothing but copy one another ... to conform to custom merely as custom does not educate or develop in [us] any of the qualities which are the distinctive endowment of a human being. The human faculties of perception, judgment, discriminative feeling, mental activity, and even moral preference are exercised only in making a choice. He who does anything [solely] because it is the custom makes no choice. He gains no practice either in discerning or in desiring what is best. ${ }^{24}$

For Mill, it is a person's own judgements that should guide his or her conduct. But this is not to say that individuals should not benefit from the knowledge and experience of predecessors. ${ }^{25}$ Rather, they should be keen to contrast this backdrop of prior knowledge and experience with a genuine assessment of their own experiences and circumstances. After all, it is careless to assume that the judgements of others are based on similar circumstances and a comparable scope of experience.

[I]t is the privilege and proper condition of a [mature] human being ... to use and interpret experience in his own way. It is for him to find out what part of recorded experience is properly applicable to his own circumstances and character. The traditions and customs of other people are, to a certain extent, evidence of what their experience has taught them: presumptive evidence, and as such, have a claim to his deference: but, in the first place, their experience may be too narrow; or they may have not interpreted it rightly. Secondly, their interpretation of experience may be correct, but unsuitable to [others]. ${ }^{26}$

Thus, Mill asks us to engage life in a certain way. He wants us to become adept at exercising reason, making choices and desiring what is best for us. When individuals blindly yield to custom, ${ }^{27}$ they disengage their faculties and fail to map their opinions to their own reasons. So far as this becomes a habit, the faculty of reason will decay. This is what leads Mill to conclude that any person willing to allow others to plan his or her life requires no 'other faculty than the ape-like one of imitation'. ${ }^{28}$ While we may try to assist others in making effective judgements by offering considerations that support or challenge their opinions, each individual should be the final judge for himself. ${ }^{29}$

While I do not think Mill should be read as overly critical of custom, there is a sense in which he may be considered, at the very least, suspicious of custom. As Jonathan Riley observes, Mill recognizes that

24 Mill, On Liberty, p. 262.

25 Mill, On Liberty, p. 262.

26 Mill, On Liberty, p. 262.

27 It might be thought that Mill would like us to give zero weight to custom in decisionmaking. This, I believe, is mistaken. For Mill is clear that custom should 'have a claim to [one's] deference'. But while one can give some weight to custom, one should never adhere to 'custom merely as custom'. See Mill, On Liberty, p. 262.

28 Mill, On Liberty, p. 262.

29 Mill, On Liberty, p. 277. 
'most people are in the habit of thinking that existing rules of conduct do not require to be impartially justified by reason'. ${ }^{30}$ What troubles Mill, then, is the social effect for which custom appears to be responsible. Though, here again, the problem does not lie with custom itself, but with the poor habits of decision-makers.

Along with his emphasis on authenticity, Mill shows an appreciation for diversity. '[D]iversity [is] not an evil, but a good ... there should be different experiments of living ... free scope should be given to varieties of character, short of injury to others. ${ }^{\text {'31 }}$ It seems, then, that a Millian defence of the worth of cultural groups - as diversity-producing groups - must be traced to the importance of encouraging individuals to experiment with different ways of living. This, I take it, is what Waldron means when he says that '[i]f there is any support in [Mill's] work for cultural diversity, it is as an aspect of individual liberty'. ${ }^{32}$

It is important to recognize that cultural diversity is just one type of diversity, broadly construed. Mill often uses the term 'diversity' to refer to what might be called 'individual diversity'. Individual diversity is what Monique Deveaux has in mind when she says that 'liberals since John Stuart Mill have tended to conceive of pluralism in terms of the diversity of individual preferences, opinions, moral views, and beliefs, rather than collective social and cultural identities and belief systems'. ${ }^{33}$ What I want to emphasize is that cultural diversity can serve as a rich source of individual diversity. ${ }^{34}$ Cultural diversity when not isolated - exposes alert individuals to alternative ways of life, providing another backdrop against which individuals can compare their own beliefs and experiences and reflect upon their upcoming pursuits.

It is also important to avoid conflating custom with culture. A cultural member can certainly reject custom without rejecting his or her culture. The tendency towards such confusion is often the result of construing culture as static. On a static view of culture, preserving a culture simply means preserving a particular set of practices and beliefs. This view regards any change or loss of such practices or beliefs as an erosion of the culture. Thus, a person who holds a static view of culture is likely

\footnotetext{
30 Jonathan Riley, Mill on Liberty (Abingdon, 1998), p. 44.

31 Mill, On Liberty, pp. 260-1.

32 Waldron, 'Mill', p. 179.

33 Monique Deveaux, Cultural Pluralism and Dilemmas of Justice (Ithaca, 2000), p. 30 .

34 This is in contrast to Bhikhu Parekh, who believes that Mill's emphasis on individual diversity prevents him from appreciating cultural diversity. See Bhikhu Parekh, Rethinking Multiculturalism (Cambridge, 2000), p. 44. This, however, overlooks the fact that an appreciation for cultural diversity can be built into an appreciation for individual diversity.
} 
to assume that cultural minority groups are grounded in a fixed set of customs that have long defined the group. ${ }^{35}$ Such a view overlooks the fact that preserving the community is a broader goal than preserving a particular set of practices and beliefs. For it is rarely the case that a cultural community can be reduced to a particular set of practices and beliefs. Moreover, the practices and beliefs that are found within nearly all cultures are constantly subject to change. ${ }^{36}$ Individual members of a culture influence the culture's panoply of practices and beliefs as much as that panoply influences them. It is for this reason that cultural diversity can persist without it being necessary to adhere strictly to the customs of one's culture. So, while Mill certainly allows weight to be given to custom when deliberating, ${ }^{37}$ there is no reason to think that cultural minorities must give excessive weight to custom (which Mill would be opposed to) as a necessary condition of preserving their culture.

Given Mill's emphasis on individuality, it is important to get clear about what constitutes the Millian individual. Such an individual can be characterized as rational, perceptive and discriminating. These developed human beings are the discoverers of new and enlightened social practices, the initiators of improved government and the sources of individual diversity. ${ }^{38}$ In effect, they are the primary contributors to social progress, which consists in improvements in the areas of knowledge, 'security of person and property', and cooperation. ${ }^{39}$

But a fully developed human being for Mill is not one of untempered individualism. Rather, the ideal character should strive to balance selfassertion with obedience. She should be self-assertive to the extent that she experiments with different ways of living - whether others

\footnotetext{
35 As Leti Volpp points out, the tendency to take up a static view of culture often applies only in discourse about minority cultures. Those inclined to such a view often drop it once they move to discussing the culture of dominant (especially western) groups. Leti Volpp, 'Feminism versus Multiculturalism', Columbia Law Review 101 (2001), pp. $1181-1218$, at 1191.

36 See Doriane Lambelet Coleman, 'Individualizing Justice through Multiculturalism: The Liberal's Dilemma', 96 (1996), pp. 1093-1167, at 1162-7; Monique Deveaux, Gender and Justice in Multicultural Liberal States (New York, 2006), p. 184; Eric Hobsbawm, 'Introduction: Inventing Tradition', The Invention of Tradition, ed. E. Hobsbawm and T. Ranger (Cambridge, 1983), pp. 1-14, at 2; Will Kymlicka, Multicultural Odysseys (Oxford, 2007), pp. 100-1; Anne Phillips, Multiculturalism without Culture (Princeton, 2007), p. 45; Parekh, Rethinking Multiculturalism, pp. 76-9.

${ }^{37}$ See the passage cited in n. 26.

38 Mill, On Liberty, pp. 267-70. See also Riley, Mill on Liberty, pp. 83-90.

39 John Stuart Mill, Principles of Political Economy, Collected Works of John Stuart Mill, vol. 3, ed. J. M. Robson (Toronto, 1965), pp. 705-9. Because economic development might be thought to be an important aspect of social progress, it should be noted that Mill regards improvements in industry to be one effect of improvements in knowledge. See John Stuart Mill, A System of Logic, Collected Works of John Stuart Mill, vol. 8, ed. J. M. Robson (Toronto, 1974), p. 926.
} 
value those experiments or not. She should be obedient in so far as she respects the rules of justice that are intended to protect the rights of others (so far as those rules are reasonable). ${ }^{40}$ It is through the process of developing one's character that life

becomes rich, diversified, and animating, furnishing more abundant aliment to high thoughts and elevating feelings, and strengthening the tie which binds every individual to the race, by making the race infinitely better worth belonging to. In proportion to the development of his individuality, each person becomes more valuable to himself, and is therefore capable of being more valuable to others. ${ }^{41}$

From this particular conception of the individual we can extract an argument for multiculturalism. It is clear that social progress (for every society and for all of humankind) is a primary goal of Mill's political theory. And diversity is one means to social progress. Therefore, Mill is theoretically justified in permitting cultural accommodations if the purpose is to promote diversity as a means to social progress. Cultural accommodations serve to promote diversity by providing visibility to cultural minorities and by protecting them from cultural assimilation. This benefits not just minority group members, but all of society by deepening the stock of life experiments to which all citizens can contrast their own opinions, experiences and pursuits.

Mill, of course, would not be committed to granting cultural accommodations that could be used to deprive individuals of any of their basic civil and political liberties - even if those accommodations would effectively promote diversity. The basis for this claim lies in Mill's defence of a purely self-regarding sphere of conduct. The idea of such a sphere is expressed by Mill's 'one very simple principle': 'the only purpose for which power can be rightfully exercised over any member of a civilized community, against his will, is to prevent harm to others'. ${ }^{42}$ As such, 'the individual is not accountable to society for his actions in so far as [those actions] concern the interests of no person but himself. ${ }^{43}$ This principle is thought to have the effect of delineating a 'region of human liberty' that entails a set of basic liberties. ${ }^{44}$ As Mill construes it, his principle secures (for all people)

liberty of conscience in the most comprehensive sense, liberty of thought and feeling, absolute freedom of opinion and sentiment on all subjects, practical or speculative, moral, or theological ... liberty of tastes and pursuits, of framing the plan of our life to suit our own character ... [the] freedom to unite for any

40 Mill, On Liberty, p. 266.

41 Mill, On Liberty, p. 266.

42 Mill, On Liberty, p. 223.

43 Mill, On Liberty, p. 292.

44 Mill, On Liberty, p. 225. 
purpose not involving harm to others: the persons combining being supposed to be of full age and not forced or deceived. ${ }^{45}$

Any society which does not secure these liberties in the absolute is not free. ${ }^{46}$ As such, Mill's 'one very simple principle' can be framed as a principle of liberty. It is in light of this principle that we can say with certainty that Mill would reject any sort of cultural accommodation that enabled minority groups to oppress individual members by infringing upon their basic liberties. But the liberty principle does more than this. It also guarantees against forced assimilation with regard to those aspects of culture that attach to the basic liberties. This is not to say that cultural minorities will not choose to assimilate culturally. It is only to say that they cannot, in principle, be either expected or forced to assimilate culturally with respect to any cultural particularity that is purely self-regarding. ${ }^{47}$

To sum up, I have claimed that Mill's argument for the nation-state can be interpreted as promoting a civic nation in which the development of effective cooperation and political participation depends on a sharing of political sympathies. This sort of nationalism expects cultural minorities to assimilate politically, but allows them individually to choose whether or not to assimilate culturally (beyond commonlanguage acquisition). I have also claimed, in agreement with Waldron, that a Millian multiculturalism must be founded on the value of diversity. As I continue to flesh out a Millian multiculturalism, it should become clear why a Millian cannot argue for multiculturalism by appeal to equality concerns. To begin to understand why this is so, we must first look at what types of cultural minorities contribute to social diversity.

\section{SOURCES OF CULTURAL DIVERSITY}

As Will Kymlicka notes, '[i]mmigration and the incorporation of national minorities are the two most common sources of cultural diversity in modern states'. ${ }^{48}$ National minorities are the members of cultural groups who inhabited a geographical region prior to incorporation into a state (e.g. indigenous peoples). According to Kymlicka, because these minorities were politically autonomous prior to incorporation, they 'typically wish to maintain themselves as distinct societies alongside the majority culture, and demand various forms

45 Mill, On Liberty, pp. 225-6.

46 Mill, On Liberty, p. 226.

47 Admittedly, this may not amount to a large set of cultural particularities. However, it demonstrates that it would be false to claim that Mill could expect or demand complete cultural assimilation. Later, I explain how multicultural policies could be instituted to preserve a wider set of cultural particularities.

48 Will Kymlicka, Multicultural Citizenship (New York, 1995), p. 24. 
of [cultural accommodations] to ensure their survival as distinct societies'. ${ }^{49}$ Such a demand is not surprising since these groups are often involuntarily incorporated.

Cultural accommodations, if granted to national minorities by the dominant culture, often come in the form of rights which are meant to promote the self-government (or political autonomy) of minority groups. These might include rights establishing territorial autonomy, strong language rights (e.g. the ability to employ one's native language when interacting with the social and political institutions of the majority culture), or even rights to establish culture-specific courts or schools. Immigrants, on the other hand, have voluntarily chosen to uproot themselves from their home country in order to integrate elsewhere, so they usually do not expect the sort of political autonomy that national minorities seek. As such, it is rare for immigrants to seek self-government rights. However, they do often seek other sorts of cultural accommodations intended to 'help them express their cultural particularity'. ${ }^{50}$ Kymlicka refers to these sorts of cultural accommodations as accommodation rights. ${ }^{51}$ These rights allow cultural minorities to preserve important cultural values without inhibiting political assimilation. This is crucial for the Millian since political assimilation is necessary to promote the civic nation. A few examples of accommodation rights are the adoption of a culturally sensitive curriculum in education, cultural representation in public media, special funding for cultural organizations or cultural development programmes, exemption rights from one or more existing policies, hunting and fishing rights, representation rights in the local and/or central government, and even some limited land rights and language rights. ${ }^{52}$

Such rights may even promote the development of civic loyalties in cultural minorities. ${ }^{53}$ Not only might cultural minorities see these

49 Kymlicka, Multicultural Citizenship, p. 10.

50 Kymlicka, Multicultural Citizenship, p. 31.

51 Will Kymlicka, Politics in the Vernacular (New York, 2001), p. 51. In his earlier work, Kymlicka refers to these sorts of rights as 'polyethnic rights'. See Kymlicka, Multicultural Citizenship, p. 31.

52 For a listing of the most common types of accommodations granted to immigrants, national minorities and indigenous peoples, see Keith Banting, Richard Johnston, Will Kymlicka and Stuart Soroka, 'Do Multiculturalism Policies Erode the Welfare State? An Empirical Analysis', Multiculturalism and the Welfare State, ed. K. Banting and W. Kymlicka (New York 2006), pp. 49-91. While it is difficult to tell exactly what sorts of rights Mill might have been sympathetic to in his time, it is interesting to consider whether a Millian multiculturalism is robust enough to accommodate recent concerns and sensibilities.

${ }^{53}$ For statistical evidence in favour of this claim, see Will Kymlicka, Finding Our Way: Rethinking Ethnocultural Relations in Canada (New York, 1998), ch. 1. 
rights as encouraging their participation in the political domain, they may also see them as indicating a respect that the dominant culture has for their traditions and values. Indeed, recently incorporated or immigrated minorities might struggle, because of a lack of shared history and experiences, to forge loyalties with the citizens of their new nation quickly, even if they do share similar political values. Accommodation rights may help to nurture these sympathies by way of the respect that attaches to cultural accommodations. ${ }^{54}$ Accommodation rights, however, should not be viewed as granting protection from competition in the 'cultural marketplace'. Rather, they should be seen as bringing cultural minorities into the marketplace by providing visibility to their ways of life and by promoting crosscultural dialogue. ${ }^{55}$ It remains the case that the persistence of any cultural group depends on the willingness of its individual members to remain in the group. From this perspective, cultural accommodations which help to bring cultural minorities into the marketplace of cultural possibilities may also serve to test that willingness. ${ }^{56}$ As such, while accommodation rights do assist cultural minorities in preserving their cultural particularity, they are not merely preservationist policies (i.e. policies which aim solely at preserving the group). ${ }^{57}$

If the thesis of this article is to retain plausibility, it must be the case that cultural accommodations will not serve to undermine political assimilation. This concern is addressed by two important qualifications that will be discussed over the remainder of this article. These qualifications are summarized as follows. First, Mill would be forced to reject any claims to self-government rights, and it is precisely these sorts of rights that are most threatening to political assimilation. As such, cultural accommodations, on Mill's account, would be limited to accommodation rights. Second, Mill would have to deny accommodation rights to any minority group that is antagonistic towards social progress - that is, antagonistic towards improvements in knowledge, security and cooperation.

I want to return now to the difference between those arguments for multiculturalism based on an appeal to equality and those based on an appeal to diversity. Arguments for multiculturalism that appeal to equality typically point to the idea that cultural accommodations

\footnotetext{
54 This, of course, is not to suggest that it is not possible for cultural minorities to assimilate politically without benefiting from such rights.

55 Parekh, Rethinking Multiculturalism, p. 223.

56 This is in contrast to self-government rights, which often serve further to isolate groups.

57 To say that accommodation rights can help to preserve a group's cultural particularity while also bringing that group into the cultural marketplace - a form of exposure - may seem problematic. But this is only so if one construes culture as static.
} 
are necessary to eliminate some inequality that burdens cultural minorities. One of the most prominent equality-based arguments for multiculturalism is defended by Kymlicka. On his account, cultural accommodations are necessary to achieve equality of selfdetermination. As he argues,

[o] ur capacity to form and revise a conception of the good is intimately tied to our membership in a societal culture, since the context of individual choice is the range of options passed down to us by our culture. Deciding how to lead our lives is, in the first instance, a matter of exploring the possibilities made available by our culture. ${ }^{58}$

Thus, supplementing the basic rights of cultural minorities with cultural accommodations serves to place cultural minorities on an equal footing with members of the majority culture with regard to the capacity for self-determination.

As we have seen, Mill is primarily concerned with whether the liberties associated with the principle of liberty have been secured. He is not concerned with differences in citizens' abilities to make use of those liberties. Take, for example, the liberty of 'framing the plan of our life to suit our own character' ${ }^{59}$ For Kymlicka, the capacity to frame, pursue and revise that plan is 'intimately tied' to one's cultural membership. Therefore, if the cultural membership is lost, so is the capacity to frame one's plan of life as one sees fit. It is for this reason that I say Kymlicka's argument for multiculturalism appeals to concerns for equality of self-determination.

It is because such an argument does not appear to be available to Mill that I believe a Millian multiculturalism cannot be rooted in equality concerns. If, however, such an argument were available, Mill would face at least one glaring problem. Given that he rejects the idea of multinational states (in normal circumstances), he could not extend self-government rights to any minority groups. Yet, on an equality-based argument, national minorities - who are often involuntarily incorporated - would certainly be candidates for selfgovernment rights. As it stands, however, Millians need not answer to this worry. Cultural accommodations, on Mill's account, can be granted only where they serve to increase diversity (as a means to social progress). Increasing equality is not a justified reason for granting supplemental rights. It seems, then, that the disadvantages that national minorities may suffer on a Millian multiculturalism are the cost to be paid for having a tightly knit political community (Mill's core reason for preferring a civic-based nation-state).

58 Kymlicka, Multicultural Citizenship, p. 126.

59 Mill, On Liberty, p. 226. 
This is not to argue that Mill does not care about equality. Again, he would flatly refuse to grant cultural accommodations to any groups that sought to infringe upon the basic civil and political liberties of its members. As seen in the discussion of the liberty principle, a Millian society guarantees all citizens the same basket of civil and political liberties, regardless of group affiliation. As such, any group that attempts to inflict wrongful harm on its individual members (or on non-members) by infringing upon their basic liberties would be subject to state interference. ${ }^{60}$

Whatever its faults, the value of diversity argument works well in Mill's case since protecting national minorities with self-government rights would encourage their political isolation, thereby undermining their expected political assimilation into Millian society. On the other hand, accommodation rights serve to protect cultural values while expecting the recipients of these rights to coalesce politically with the dominant culture. ${ }^{61}$ And since Mill seeks to establish a public domain where these cultures can engage in free and open discussion, it is here that individuals will come to know the opinions and practices of others by which they can critique their own pursuits.

It might be objected that the conceptual ground of cultural accommodations - 'group rights' - is something Mill would have rejected. As the objection might run, group rights endow some 'authority' within the group to dictate how the received rights are to be exercised. But this serves to undermine the clear emphasis that Mill places on individuality. As such, it is mistaken to suggest that Mill would have been hospitable to any form of multiculturalism. Such an

60 This is not to suggest that individuals cannot join groups which restrict their basic liberties. As long as these associations are voluntary, and remain voluntary, such restrictions would not constitute wrongful harm. Although the Mormons are not an ethnic group, Mill's remarks on them may be helpful here. In the case of Mormons in the nineteenth century, Mill (On Liberty, p. 291) advocated non-interference as long as (1) the Mormons did not act aggressively towards other communities; (2) their individual members retained a right to exit; and (3) individual members did not reach out to other communities for protection against the Mormon doctrine. While conditions (2) and (3) appear jointly to establish voluntariness for Mill, it is debatable whether a right to exit is anything but merely formal (rather than substantial) with regard to groups which people are born into or raised in. For this reason, cultural groups - which individuals are often born into - typically deserve more scrutiny than social groups.

61 While one might argue that certain cultural groups should have a claim to selfgovernment rights, there is no reason to think that the maintenance of cultural diversity requires self-government rights. If this were the case, then we would expect all immigrant groups in Australia, Britain, Canada, New Zealand, Sweden and the United States to be unsuccessful at maintaining their cultures. But this has not been the case. That said, we can certainly distinguish between 'thick' and 'thin' accounts of multiculturalism. So, while there is no reason to think that a multiculturalism that rejects self-government rights cannot maintain cultural diversity, it can properly be labelled a 'thin' account of multiculturalism - and this may be unappealing to some advocates of multiculturalism. 
objection, however, rests on the erroneous presumption that cultural accommodations can be construed only as group-exercised rights. Most, if not all, of the cultural accommodations that Mill could endorse (those in the form of accommodation rights) can be construed as individual rights. ${ }^{62}$ Doing so allows the proper subject of liberalism - individuals to choose for themselves how to manage the benefits of such rights, as opposed to some authority within the group who, with respect to a group-exercised right, may be in a position to disregard the legitimate claims of individual members ${ }^{63}$ What is important to recognize is that even if cultural accommodations are not group-exercised, they are still group-delineated, and it is this fact that keeps us engaged in discourse about multiculturalism.

Perhaps the clearest example of accommodation rights compatible with the Millian framework will be those that take the form of exemption rights. Such rights can be construed as individual rights, do not undermine political assimilation, and assist with the maintenance of minority cultures. Of course, the sorts of exemption rights that may be entertained in a Millian society will depend on the sorts of policies that have been instituted. A couple of well-known examples of exemption rights are the 1976 act in Britain exempting Sikhs from having to wear crash helmets when operating motorcycles and the British Employment Act of 1989, which exempted Sikhs from having to wear safety helmets while working at construction sites.

Accommodation rights in the form of representation rights may also have a place in the Millian framework. Such rights may be helpful in promoting the development of political sympathies of incorporated minorities. This could entail reserving seats in legislative bodies for cultural minorities (as New Zealand has done for the Maori people) or assisting minority groups with establishing representative bodies which are responsible for generating dialogue regarding policies which may have cultural impact (as Norway has done for the Sami people). ${ }^{64}$

Furthermore, while Mill would expect common-language acquisition, this does not rule out the possibility that funding could be provided for bilingual education to assist with political assimilation ${ }^{65}$ or that those schools established by the state 'as one among many competing

\footnotetext{
62 It may be more difficult to construe self-government rights in the form of individual rights. But, as I have argued, Mill must reject any claims to self-government rights in the first place.

63 Rejecting the extension of group-exercised rights does not prevent individuals from choosing to subject their individual rights to collective exercise as they see fit.

${ }^{64}$ In such instances, each individual in the community would possess a right to compete for reserved seats (e.g. through culture-specific elections).

65 See, for example, the U.S. Bilingual Education Act of 1968.
} 
experiments ${ }^{36}$ could incorporate a curriculum which recognizes ethnic diversity by discussing the history and culture of various cultural groups. The same goes for land rights. Just because Mill would not want cultural minorities to isolate themselves territorially and politically through self-government rights, it does not follow that land rights would be flatly impermissible. For example, special hunting and fishing rights could be granted to cultural minorities under certain circumstances. This may be especially pertinent with regard to recently incorporated territories.

\section{JUSTICE}

The first paragraph of the following passage is a favourite of Millian commentators, while the second is sometimes overlooked.

Experience proves that it is possible for one nationality to merge and be absorbed in another; and when it was originally an inferior and more backward portion of the human race the absorption is greatly to its advantage. Nobody can suppose that it is not more beneficial to a Breton, or a Basque of French Navarre, to be brought into the current of the ideas and feelings of a highly civilized and cultivated people - to be a member of the French nationality, admitted on equal terms to all privileges of French citizenship, sharing the advantages of French protection and the dignity and prestige of French power - than to sulk on his own rocks, the half-savage relic of past times, revolving in his own little mental orbit, without participation or interest in the general movement of the world.

Whatever really tends to the admixture of nationalities and the blending of their attributes and peculiarities in a common union is a benefit to the human race. Not by extinguishing types ... but by softening their extreme forms and filling up the intervals between them. The united people, like a crossed breed of animals ... inherits the special aptitudes and excellences of all its progenitors ...67

This passage is a glaring admission of the emphasis Mill places on social progress. However, it is important to recognize that this absorption is only discussed in light of the assumed inapplicability of Mill's general principle of nationality ${ }^{68}$ In particular, Mill is considering cases in which geographical complications necessitate that two nations come together under a single government. To be sure, Mill is not advocating a multinational state here. Rather, his talk of absorption indicates that his intention is for two nations to become one.

A number of points are needed here. That Mill would expect 'absorption' is not a surprise given his preference for the nation-state

66 Mill, On Liberty, p. 302.

67 Mill, Considerations, pp. 549-50.

68 Once more, Mill's general principle of nationality says that government boundaries should coincide with single nationalities. 
model. However, we should not conclude from this that Mill ignores the worth that minority cultures can bring to a larger society. It is true that, as incorporated minorities, neither the Bretons nor the Basques could claim rights to self-government. After all, that would conflict with the nation-state model. The only expected assimilation would be political assimilation in line with Mill's conception of the civic nation. The emphasis on the political is clear in the passage. Mill believes the Bretons and the Basques would benefit greatly from a new 'current of ideas', from being 'a member of the French nationality', obtaining the 'privileges of French citizenship' and benefiting from the 'prestige of French power'. Why does Mill think all this will be helpful to the Bretons and Basques? He thinks it will serve to develop in them an interest in 'the general movement of the world'.

To be sure, Mill is not implying that the cultural practices of the Bretons and Basques must be entirely dispensed with. If anything is wrong with their culture, so to speak, it is the failure to incite in its members an interest in the improvement of the world. To remedy this, Mill would not extend self-government rights to them, if incorporated. His hope is that a refusal of self-government rights, along with common-language acquisition (where applicable), would lead to effective cooperation and political participation. Mill, then, as Georgios Varouxakis recognizes, 'did not mean the absolute absorption and disappearance of the [absorbed] group ... what [he] had in mind was a kind of heterosis, whereby the best qualities of each group would be preserved and enhanced'. ${ }^{69}$ In the case of the Breton and Basque cultures, it is evident that Mill thought that they would benefit from participation in a political domain that was saturated by concerns with the improvement of humankind. But this does not, in itself, call for significant cultural assimilation.

It is one thing to claim that Mill would not expect incorporated groups to assimilate into the cultural sphere (beyond common-language acquisition), but it is quite another to claim that there is definite space for cultural accommodations in both Mill's moral and political framework. While I do not want to engage in a detailed discussion of the relationship between Mill's utilitarianism and justice, I do want to reject the idea that policy justifications, for Mill, are simply a matter of respecting a narrow reading of the principle of utility. 'Utility, or the Greatest Happiness Principle, holds that actions are right in proportion as they tend to promote happiness, wrong as they tend to produce the reverse of happiness. ${ }^{70}$

69 Georgios Varouxakis, Mill on Nationality (London, 2002), pp. 10-11.

70 John Stuart Mill, Utilitarianism, Collected Works of John Stuart Mill, vol. 10, ed. J. M. Robson (Toronto, 1969), p. 210. 
Mill is concerned with more than just the direct consequences, in terms of happiness, that are produced by the actions of either individuals or political institutions. As he remarks,

The recognition of happiness as the only thing desirable in itself, and of the production of the state of things most favourable to happiness as the only rational end both of morals and policy, by no means necessarily leads to the doctrine of expediency as professed by Paley; the ethical canon which judges of the morality of an act or class of act, solely by the probable consequences of that particular kind of act, supposing it to be generally practiced. This is a very small part indeed of what a more enlarged understanding of the 'greatest-happiness principle' would require us to take into account. ${ }^{71}$

Mill's position is reiterated in his criticism of Jeremy Bentham.

A theory ... which considers little in an action besides that action's own consequences ... will be most apt to fail in the consideration of the greater social questions - the theory of organic institutions and general forms of polity; for those ... to be duly estimated, must be viewed as the great instruments of forming the national character; of carrying forward the members of the community towards perfection, or preserving them from degeneracy. This, as might in some measure be expected, is a point of view in which, except for some partial or limited purpose, Mr. Bentham seldom contemplates these questions ... And this signal omission is one of the greatest of the deficiencies by which his speculations on the theory of government, though full of valuable ideas, are rendered, in my judgment, altogether inconclusive in their general results. ${ }^{72}$

It is Mill's displeasure with Paley and Bentham, perhaps, that prompts him in On Liberty to construe utility as follows. 'I regard utility as the ultimate appeal on all ethical questions: but it must be utility in the largest sense, grounded on the permanent interests of man as a progressive being. 73

Whatever particular type of utilitarian Mill is,${ }^{74}$ his comments here suggest that social policies and political institutions are to be arranged so as to promote social progress in the long term. If this is right, it means that even if a multicultural policy would fail to maximize utility in the near term, the utility principle could authorize such a policy as long as the promotion of diversity would help to advance social progress. Thus, it is consistent with Mill's political theory to extend accommodation rights, in one form or another, to incorporated

\footnotetext{
71 John Stuart Mill, Remarks on Bentham's Philosophy, Collected Works of John Stuart Mill, vol. 10, ed. J. M. Robson (Toronto, 1969), p. 7.

${ }^{72}$ Mill, Remarks, p. 9.

73 Mill, On Liberty, p. 224. I am setting aside the issue of what precisely the 'permanent interests' are - an issue which is the subject of much debate. For two discussions of the issue see John Gray, Mill on Liberty: A Defence (London, 1983), ch. 3, and Jonathan Riley, Liberal Utilitarianism (Cambridge, 1988), ch. 9.

74 It may be the case that Mill does not fit neatly into either an act-utilitarian or rule-utilitarian camp.
} 
minority groups. Moreover, because advancing social progress is a crucial component of the general happiness, the promotion of cultural diversity, when subject to certain restrictions, becomes a factor in the promotion of that happiness. And because promoting the general happiness is Mill's ultimate goal, it is reasonable to think that he would have been hospitable to promoting cultural diversity.

As briefly noted earlier, I do believe that at least one other important condition must apply. While all incorporated minorities would not be expected to assimilate into the cultural sphere (beyond common-language acquisition), it is likely that Mill's framework would justify cultural accommodations only for those groups which are not antagonistic towards social progress. In section IV, I argued that Mill is vehemently critical not of custom itself, but of individuals who passively accept custom as authoritative when making important life choices. Mill, then, would be deeply critical of any group that touted custom as the sole guide to be appealed to when forming one's life plans. This condition reaffirms Waldron's observation that Mill values diversity only 'as a means to [social] progress'. ${ }^{75}$ Cultural accommodations could not be justified within a Millian framework merely because they promote diversity. Any incorporated group that is antagonistic towards social progress would likely be ineligible for such protections, even if those protections helped to preserve diversity. In other words, where diversity is somehow restricted from serving as a means to social progress, appeals to diversity cannot justify cultural accommodations.

A proponent of a strong liberal multiculturalism would arguably find such a condition unacceptable. For it implies that Mill would expect incorporated groups to take up the practices of the dominant group. But this is too quick. The concern is with cultural groups that encourage the suppression of individuality for the purpose of preserving its culture. Mill would have nothing against a cultural group touting their practices as worthy of adoption. His criticism would be reserved for those groups that discourage members from questioning the practices of their group.

Whether the Bretons or Basques would have been candidates for cultural accommodations is debatable. The issue would be likely to turn on whether they were antagonistic towards social progress or, as Mill seems to imply, simply oblivious to the world around them. To be sure, if any cultural accommodations could be granted, determining the precise nature of those rights would depend on the circumstances of time and place. Nevertheless, I do not think there should be any doubt about whether Mill's theoretical framework provides space for at least some multicultural considerations.

75 Waldron, 'Mill', p. 183. 


\section{CONCLUSION}

I have proposed the parameters for the most robust account of multiculturalism that I believe would be compatible with Mill's liberal framework. While one may certainly question whether or not such an account of multiculturalism founded on promoting diversity as a means to social progress is ideal, ${ }^{76}$ it is important to emphasize that Mill never, at least as it appears to me, set out to defend any sort of multiculturalism. He surely would not have been familiar with much of the language used today in discussions about multiculturalism. For this reason, I do not want to overstate the work that such a multiculturalism can do. It is indeed a modest formulation.

Alternatively, one might worry that Mill's argument for the civic nation depends on some questionable claims. For example, one idea that is open to criticism is the idea that the government of a multinational state would be able to manipulate the separate nations to such a degree that their distrust of one another prevents the possibility of a joint resistance. It is this idea that leads Mill to believe that nationstates are necessary to the development of effective cooperation and political participation. Yet, it is not clear that the separate nations of a multinational state could be so easily manipulated and, because of this, it is not clear that the possibility of resistance is more easily secured in nation-states than it is in multinational states. That said, my focus has been not on critiquing Mill's conception of the civic nation, but on trying to determine what sort of multiculturalism can follow from it.

To summarize, Mill cannot permit cultural accommodations in the form of self-government rights. This would be incompatible with his conception of the civic nation. Nor do I think that Mill would permit cultural accommodations in the form of group-exercised rights. He would, however, allow for accommodation rights, construed as individual rights, which assist cultural minorities in preserving their cultural particularity. Further, while national minorities may have a legitimate claim to self-government rights on an appeal to equality concerns, they, like immigrants, are limited to accommodation rights on the Millian account. Such rights would be permissible only in so far as they (1) promote diversity as a means to social progress; (2) do not impede the political assimilation of cultural minorities; and (3) do not enable groups wrongfully to harm individual group members (or non-members) by infringing upon their basic civil and political liberties. This, I suggest, is the thickest account of multiculturalism compatible

\footnotetext{
76 For criticisms of diversity-based arguments for multiculturalism, see Steven Wall, 'Collective Rights and Individual Autonomy', Ethics 117 (2007), pp. 234-64, at 239-41. See also Kymlicka, Multicultural Citizenship, pp. 121-3.
} 
with Mill's political framework. As noted in the introduction, I believe the benefit of laying out a pointed account of Mill's multiculturalism is that it should give us a better basis from which to label Mill's own practical conclusions - where cultural minorities are concerned - either consistent or inconsistent with his theoretical framework. ${ }^{77}$

jtyndal@tulane.edu

77 I am especially grateful to Eric Mack and Jonathan Riley for their many helpful comments on earlier drafts of this article. I would also like to thank one anonymous referee for this journal for providing helpful comments. 